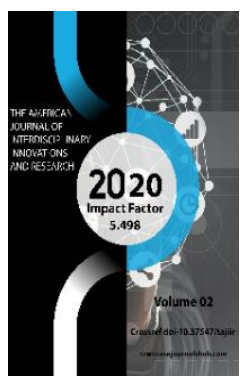

\title{
From The History Of The Emergence Of Cities In The Mirzachul Region
}

\author{
Saydullo Oxunov
}

Researcher, Samarkand State University, Samarkand, Uzbekistan

Journal Website: http://usajournalshub.c om/index,php/tajiir

Copyright: Original content from this work may be used under the terms of the creative commons attributes 4.0 licence.

\section{ABSTRACT}

Mirzachul regions were part of the historical region of Ustrushna in ancient times. The article notes that Ustrushana is not only a country suitable for animal husbandry, but also a developed agricultural culture in its fertile plains, which are connected with the steppes. The urban culture of the ancient and medieval Ustrushona is illustrated by such monuments as Eski Havas, Ordatepa, Qaliyatepa, Oydinsoytepa, Qurghontepa. It is noted that the Sangzor and Zamin rivers and a number of small rivers played an important role in the development of these settlements. The article reflects the historical, historical structure, objective historical analysis of artifacts.

\section{KEYWORDS}

Central Asia, East, West, Ustrushana, Syrdarya, Mirzachul, Khujand, Ferghana, Shahrukh, Kurkat, Rustaq, bathhouse, medieval, coin, brick, ceramic

\section{INTRODUCTION}

Today, Jizzakh and Syrdarya regions, located in the main part of Mirzachul, were inhabited in ancient times by representatives of the agricultural population. Ustrushona is located in the central part of Central Asia, most of which consists of deserts and steppes. The relief of Ustrushona is unique, and the confluence of mountain, foothill, steppe and plain (desert) zones is its peculiarity. A large part of the country was occupied by Mirzachul, whose land structure consisted of plains. It descends from southeast to 
northwest. The plain is sloping to the northwest, with an average height of $250-300 \mathrm{~m}$ above sea level, and $450-530 \mathrm{~m}$ in the southern foothills. The relief of the southern part consists of the Turkestan ridges and its western Morguzar and Chumkartov mountains (2500-3000 $\mathrm{m}$ in height, $800 \mathrm{~m}$ in the Jizzakh part). From the north and northeast, the stair-shaped plains rise towards the mountains. This region is a unique microregion of Uzbekistan, consisting of high and medium-altitude mountains, foothill plain oases, sandy and desert landscapes. Initially, these territories were part of the ancient state of Sughd, and later part of the independent state of Ustrushna. A unique culture of farming and animal husbandry has emerged here. In ancient times, the arrival of GrecoMacedonian armies in these areas led to the construction of fortifications, caravan routes, resting places, cisterns, river crossings, and over the years, cities were formed in the same places.

\section{THE MAIN FINDINGS AND RESULTS}

The Great liak road in a sense also played an important role in the life of the ancient Mirzachul. By the Middle Ages, with the expansion of trade routes and the possibility of caravans to enter the pastoral peoples, cities began to appear in Mirzachul. Such cities are Nurata (Khushkat) in Sayhunabad district, Eski Havos, Kultepa near the present-day village of Savot in Yangiabad district.

According to medieval written sources, Havas was located at the crossroads of the road east of Samarkand. One branch went through Kurkat to Khojand and Fergana, the other to the north after crossing the Syrdarya, to the large city of Banokat (Shohrukhiya), and then to the second largest city, Harashkent, and finally to the capital of Chach, Binkat. In the Middle Ages, the Havas Road and the Binkat
Road were interconnected and were widely known on the Great Silk Road. V.V. According to Barthold, there were two routes to the Chirchik River valley, one of which was through Havos and the other through Jizzakh [1, p. 388]. Similarly, it was possible to go from Havas to Binkat by two routes. The first road was short and led to Khushket, a town on the crossing through Mirzachul. The city of Khushket was located on the site of Nurata Shahristan in Sayhunabad district of Syrdarya region. The second road was longer and safer, running along the right bank of the Syrdarya River, i.e. through Old Havas. Although it was possible to travel from Bunjikat, the capital of Ustrushna, to Havas via Sabot, the caravans to Fergana usually traveled through Havas and Kurkat [2, pp. 214-223]. There was also a road to Havas from the provincial capital, Bunjikat, through Sabot, another major city in Ustrushana. Although the "Great Road" passed through Sabot from the south, trade caravans generally found it convenient to travel to Khojand and Fergana via Havas and Furkat [3, p. 21]. The importance of Havasu, its strategic convenience, lies in the fact that on the one hand it is located at the crossroads of ancient important trade and military routes from west to east and from north to south through Bunjikat to Bactria. Arab geographers mention it only as a place at the crossroads of caravan routes. The Arab traveler Ibn Hawqal wrote about the way of Hawass: "If anyone wants to go from Zaamin to Khojand on the way of Hawas, he will meet Kurkat on his way." Havas is one of the destinations of Ustrushna, which is mentioned in practically all medieval road guides as the address of the way from Sogdia through Ustrushna to Chach, Khojand, Fergana and back. According to Yakut (13th century), "Havos is a village in Ustrushana" [4, p. 64]. Ibn Khordadbeh (ninth century), in his famous Book of Roads and 
Countries, dwells on the distances from Hawass to neighboring areas and from them to Hawas. Similar information about Hawass is found in the works of Qudama, Ibn Rusta (first half of the tenth century), Al-Istahri, Ibn Hawqal (tenth century), As-Samani (twelfth century), Yaqut (thirteenth century), and Abul-Fida (fourteenth century). are given. At the beginning of the 11th century, Havas, the last representative of the Samanid dynasty, is mentioned in the details of the battle between Muntasir and the Karakhanid dynasty [5, p. 388. ].

The part of the trade route connecting Bukhara, Samarkand and Chach passed through the northern regions of Mirzachul. The economic growth of Central Asia in the post-Arab period is explained by the fact that Mirzachul was located on a caravan route. A separate network was formed from the Sughd-Khojand-Fergana caravan road passing through the southern part of Mirzachul, ie the road to Chach via the Syrdarya. It should be noted that this road, in turn, led to the development of the cities of Old Havos, Khushkat on the Syrdarya.

All of the above-mentioned monuments date back to the X-XII centuries, mainly located on caravan routes, and some of them later became a place of transition from the Syrdarya to neighboring areas. The end of this caravan route led to the city of Nurata or Khushkat. After going to Khushkat, the caravan routes continued from Syrdarya directly to Binokent and from there to Chach.

The development of this caravan route in the IX-XI centuries was due to the intensification of looting attacks on trade caravans from the north, inhabited by nomads, and the intensification of trade and economic relations between the regions. The monument of Nurata city is located in Sayhunabad district, on the territory of Sholikor collective farm, on the bank of Syrdarya. The urban area was 4045 hectares, during the development of the reserve lands part of the city remains was added to the arable lands, part of which is a modern village, and the remaining 7.5 hectares are allocated for the cemetery. The city was founded in the late ninth century as a fortress, where caravans passed to the city of Binokent on the right bank of the Syrdarya. Life in the city lasted until the first half of the eleventh century. The second development of city life dates back to the period after the Mongol invasion. The city was called Khushkat in the Middle Ages.

Remains of pottery found at the Nurata city monument, numismatic findings prove that the city was in close contact with Chach in all areas. On the other hand, there is material evidence that the cities of Ustrushna were in close contact with the Samanid city of Kultepa (Sovot).

From the appearance of the ruins of the city, it can also be seen that there was a central tower in the city, with a central street running from north to south of the city. The role of trade routes connecting the southern provinces of Movarounnahr with the northern regions was special in the development of the city. According to Arab geographers and tourists, the trade route passed through Hawass. According to the historian and traveler Ibn Khurdodbek, the distance from Hawas to the Ash-Shash River was 9 fars.

According to A.A. Gritsina, one of the archaeologists who studied the ancient history of our country, in front of the city of Binokent in the IX century there was a caravanserai at the crossing of the river. [2, 24 p. ] 
The pottery that existed in Chach at that time was also found here. Of course, this is natural, it is also the basis for the fact that the distance is not so long and trade is booming. Later, a city was formed around the caravanserai. Near Shurkul, there were caravanserais in Uchyogoch, Mirza-Rabot, and Kallatepa, now located in the Boyovut Association of Companies in Gulistan District. Archaeologists ME Masson, YF Buryakov and Russian historian VF Karavaev wrote that they saw the remains of caravanserais in the abovementioned areas.

\section{CONCLUSION}

The Arab geographer Kudama also wrote about these caravanserais in his time. The formation of the city of Khushkat (Nurata) is inextricably linked with the formation and rise of the Samanid state. The role of Bukhara as the capital of the Samanid state in the development of regional cities is also very important. The city of Nurata, which was formed as a result of the new economic rise of a new state, gradually fell into ruin with the decline of the Samanid state. As early as the middle of the 10th century, with the formation of a new caravan crossing in the upper reaches of the Syrdarya, the city of Khushkat also lost its significance. Our above thoughts confirm that the culture of the city in Mirzachul is connected with the passage of the Great Silk Road.

The development of Mirzachul and the construction of new cities on its territory is a separate issue. The reason is the development and construction of Mirzachul, which in the past occupied the territory of South Kazakhstan, Syrdarya and partly Jizzakh regions.

\section{REFERENCES}

1. Bartold V.V. Turkestan in the era of the Mongol invasion. Op. Volume 1. M, 1963. (Bartold V.V. Turkestan in the era of the Mongol invasion. Op. Volume 1. M, 1963).

2. Gritsina A.A. The Ustrushanskies were. Tashkent, 2000 (Gritsina A.A. Ustrushansky were. Tashkent, 2000).

3. Betger E.K. Extracts from the book "Ways and Countries" by Abu-I-Kasim ibn Haukal // Proceedings of SAGU. Archeology of Central Asia. Tashkent, 1957. (Betger E.K. Extracts from the book "Ways and Countries" by Abu-I-QassimibnHaukal // Transactions of SASU. Archeology of Central Asia. Tashkent, 1957).

4. Negmatov N.N. Ustrushana in antiquity and early Middle Ages. Dushanbe, 1957. (Negmatov NN Destroyed in antiquity and the early Middle Ages. Dushanbe, 1957).

5. Ibn Khordadbeh. Book of paths and countries. Per. from Arabic, comments, research, pointers and maps by $\mathrm{N}$. Velikhanova. Baku, 1986. (IbnKhordadbeh. Book of ways and countries.Per. From Arabic, comments, research, pointers and maps of N. Velikhanova. Baku, 1986 /

6. Karavaev V.F. The Hungry Steppe in its Past and Present-SPb., 1914.

7. Hungry Steppe, 1867-1917 History of the region in documents. M. 1981. 